\title{
Penggunaan Media Pembelajaran Berbasis ICT Dan Pengaruhnya Terhadap Tingkat Kelulusan Ujian Nasional Siswa Pada Sekolah Menengah Di Kota Palopo (Studi Kasus Di 5 Sekolah Menengah Di Kota Palopo)
}

\author{
Rosdiana \\ Prodi Tadris Matematika, FTIK, IAIN Palopo \\ Jl. Agatis, Kel. Balandai, Kota Palopo, Indonesia \\ E-mail: rosdiana@iainpalopo.ac.id
}

\begin{abstract}
Mastery of ICT in the professional work of faculty strongly supports the effectiveness and success in implementing tasks faculty's ability to understand and apply ICT-based learning media is diverse, so the effect is given to student learning outcomes also vary. This study also aims to provide information to the perpetrators of the educators extent of influence the application of ICT-based learning media to encourage them to improve their skills and their professionalism as teachers in developing instructional media used. Media ICT-based learning affects the learning outcomes of students in a particular class of National Examination in three (3) years) this. From the description of the data we collect see the value of the average results of students of National Examination within three (3) years in five (5) secondary school located in the town of Palopo and the type of media used by teachers, it appears that there tend to be differences in test scores better for students whose teachers use ICT-based learning media compared to teachers who do not use ICT.
\end{abstract}

Keywords: Media of Learning, ICT, National Exam Results, TIK.

\begin{abstract}
Abstrak
Penguasaan TIK dalam profesionalitas kerja seorang tenaga pengajar sangat menunjang efektifitas dan keberhasilan dalam melaksanakan tugas Kemampuan tenaga pengajar dalam memahami dan mengaplikasikan media pembelajaran berbasis ICT ini memang beragam, sehingga pengaruh yang diberikan terhadap hasil belajar siswa pun beragam. Penelitian ini juga bertujuan memberikan informasi kepada pelaku pendidik sejauh mana pengaruh penerapan media pembelajaran berbasis ICT ini sehingga dapat mendorong mereka untuk meningkatkan keterampilan dan profesionalisme sebagai tenaga pengajar dalam mengembangkan media pembelajaran yang digunakan. Media pembelajaran berbasis ICT sangat berpengaruh terhadap hasil belajar siswa khususnya nilai dari Ujian Nasional pada 3 (tiga) tahun terakhir) ini. Dari gambaran data yang kami peroleh terlihat nilai rata-rata dari hasil Ujian Nasional Siswa dalam 3 (tiga) tahun terakhir di 5 (lima) sekolah menengah yang berada di kota Palopo dan jenis media pembelajaran yang digunakan oleh para pengajarnya, terlihat bahwa cenderung terjadi perbedaan hasil ujian yang lebih baik bagi siswa yang pengajarnya menggunakan media pembelajaran berbasis ICT dibandingkan dengan pengajar yang tidak menggunakan ICT dalam media pembelajarannya
\end{abstract}

Kata Kunci: Media Pembelajaran, ICT, Hasil Ujian Nasional, TIK. 


\section{Pendahuluan}

Media pembelajaran merupakan alat bantu dari proses pembelajaran yang sangat memegang peranan penting dalam kelangsungan proses belajar mengajar baik pembelajaran formal maupun non formal. Beragam media pembelajaran yang digunakan oleh tenaga pengajar dalam menyampaikan materi pengajarannya, yang disesuaikan dengan kemampuan dan kapasitas tenaga pengajar itu sendiri dalam menggunakannya.

Pada mulanya media hanya dianggap sebagai alat bantu mengajar (teaching aids). Alat bantu yang dipakai adalah alat bantu visual misalnya gambar, model, objek dan alat-aat lain yang memberikan pengalaman konkret, motivasi belajar serta mempertinggi daya serap dan retensi belajar siswa. Namun sayangnya, karena terlalu memusatkan perhatian pada alat bantu pembelajaran yang dipakai para pengajar kurang memperhatikan aspek disain, pengembangan pembelajaran produksi dan evaluasinya.Sudah selayaknya media tidak lagi hanya dipandang sebagai alat bantu belaka bagi para pengajar, tetapi lebih sebagai alat penyalur pesan dan pemberi pesan ke penerima pesan (siswa/pelajar). Oleh karena itu sebagai penyaji dana penyalur pesan dalam hal-hal tertentu media dapat mewakili guru menyampaikan informasi secara lebih teliti, jelas dan menarik.

Perkembangan teknologi informasi dan komunikasi, yang biasa disebut dengan ICT (Information and Comunication of Technologi) saat ini semakin mendorong upaya-upaya pembaharuan dalam pemanfaatan hasil teknologi dalam proses belajar mengajar, sehingga para tenaga pengajar/guru dituntut untuk mampu mengembangkan keterampilan dalam membuat media pembelajaran yang akan digunakan sehingga tujuan pembelajaran dapat tercapai. ICT sebagai suatu media dalam pendidikan juga mempunyai sebuah kecenderungan yang mampu mendorong minat peserta didik dan juga memberi manfaat yang banyak terhadap proses pembelajaran. Namun kenyataan di lapangan, masih banyak tenaga pengajar yang belum menggunakan media pembelajaran berbasis ICT ini dalam menyampaikan materi pengajarannya.

Pemanfaatan teknologi berbasis komputer pada sistem pengajaran merupakan suatu cara penyampaian materi dengan menggunakan sumbersumber yang berbasis mikro-prosessor dimana informasi/materi penhgajaran disimpan dalam bentuk digital dengan proses penyajian menggunakan beberapa aplikasi program yang mendukung materi yang akan disampaikan. Aplikasi tersebut apabila dilihat dari cara penyajian dan tujuan yang ingin dicapai biasanya meliputi tutorial (tahapan/langkah-langkah) serta practice (latihan) sehingga menghasilkan suatu bahan pengajaran yang interaktif antara tenaga pengajar dan siswa. 
Namun yang menjdi kendala kecenderungan tenaga pengajar menggunakan media pembelajaran yang konvensional seolah sudah menjadi "kenyamanan" tersendiri buat mereka sehingga membuat para tenaga pengajar tidak mempunyai keinginan untuk mengembangakan media pembelajaran yang sudah ada. Selain itu juga kemauan dan kemampuan untuk mempelajari pengembangan media pembelajaran berbasis ICT ini dirasakan sangat sulit oleh mereka karena dipahami segala hal yang berkenaan dengan ICT pasti erat kaitannya dengan alat yang digunakan yaitu komputer, sementara penguasaan mereka tentang komputer ini begitu minim.

Kemampuan tenaga pengajar dalam memahami dan mengaplikasikan media pembelajaran berbasis ICT ini memang beragam, sehingga pengaruh yang diberikan terhadap hasil belajar siswa pun beragam. Hal ini yang mendasari peneliti mengangkat topik tersebut untuk mengetahui bagaimana pengaruh penggunaan media pembelajaran di beberapa sekolah menengah yang ada di kota Palopo terhadap hasil belajar khususnya terhadap hasil kelulusan Ujian Nasional (UN) siswanya.

\section{Kerangka Teoretis}

Dalam suatu proses belajar mengajar, dua unsur yang sangat penting adalah metode mengajar dan media pengajaran. Kedua aspek ini saling berkaitan. Pemilihan salah satu metode mengajar tertentu akan mempengaruhi jenis media pengajaran yang sesuai, meskipun masih ada berbagai aspek lain yang harus diperhatikan dalam memilih media, antara lain tujuan pengajaran, jenis tugas dan respon yang diharapkan siswa kuasai setelah pengajaran berlangsung, dan konteks pembelajaran termasuk karakteristik siswa. Meskipun demikian, dapat dikatakan bahwa salah satu fungsi utama media pengajaran adalah sebagai alat bantu mengajar yang turut mempengaruhi iklim, kondisi, dan lingkungan belajar yang ditata dan diciptakan oleh tenaga pengajar.

Hamalik mengemukakan bahwa pemakaian media pengajaran dalam proses belajar mengajar dapat membangkitkan keinginan dan minat yang baru, membangkitkan motivasi dan rangsangan kegiatan belajar, dan bahkan membawa pengaruh-pengaruh psikologis terhadap siswa. ${ }^{1}$

\footnotetext{
${ }^{1}$ Azhar Arsyad, Media Pembelajaran (Jakarta: Raja Grafindo Persada, 2007), 15.
} 
Secara umum, manfaat media dalam proses pembelajaran adalah memperlancar interaksi antara tenaga pengajar dengan siswa sehingga pembelajaran akan lebih efektif dan efisien. Tetapi secara lebh khusus ada beberapa manfaat media yang lebih rinci Kemp dan Dayton (1985) misalnya, mengidentifikasi beberapa manfaat media dalam pembelajaran yaitu :

1) Penyampaian materi pelajaran dapat diseragamkan

2) Proses pembelajaran menjadi lebih jelas dan menarik

3) Proses pembelajaran menjadi lebih interaktif

4) Efisiensi dalam waktu dan tenaga

5) Meningkatkan kualitas hasil belajar siswa

6) Media memungkinkan proses belajar dapat dilakukan dimana saja dan kapan saja

7) Media dapat menumbuhkan sikap positif siswa terhadap materi dan proses belajar

8) Merubah peran tenaga pengajar ke arah yang lebih positif dan produktif. $^{2}$

Manfaat praktis media pembelajaran di dalam proses belajar mengajar sebagai berikut :

1) Media pembelajaran dapat memperjelas penyajian pesan dan informasi sehingga dapat memperlancar dan meningkatkan proses dan hasil belajar

2) Media pembelajaran dapat meningkatkan dan mengarahkan perhatian anak sehingga dapat menimbulkan motivasi belajar, interaksi yang lebih langsung antara siswa dan lingkungannya, dan kemungkinan siswa untuk belajar sendiri-sendiri sesuai dengan kemampuan dan minatnya

3) Media pembelajaran dapat mengatasi keterbatasan indera, ruang dan waktu

4) Media pembelajaran dapat memberikan kesamaan pengalaman kepada siswa tentang peristiwa-peristiwa di lingkungan mereka, serta memungkinkan terjadinya interaksi langsung dengan tenaga pengajar, masyarakat, dan lingkungannya misalnya melalui karya wisata. Kunjungan-kunjungan ke museum atau kebun binatang. ${ }^{3}$

${ }^{2}$ Azhar Arsyad, Media Pembelajaran (Jakarta: Departemen Pendidikan Nasional Jenderal Pendidikan Dasar Menengah Direktorat Tenaga Kependidikan, 2003), 17.

${ }^{3}$ Arsyad, Media Pembelajaran, 2007, 27. 
Pada dasarnya media berfungsi untuk tujuan instruksi dimana informasi yang terdapat dalam media itu harus melibatkan siswa baik dalam benak atau mental maupun dalam bentuk aktivitas yang nyata sehingga pembelajaran dapat terjadi. Materi harus dirancang secara sistematis dan psikologis dilihat dari segi prinsip-prinsip belajar agar dapat menyiapkan instruksi yang efektif disamping menyenangkan, media pembelajaran harus dapat memberikan pengalaman yang menyenangkan dan memenuhi kebutuhan perorangan siswa.

\section{Jenis-Jenis Media Pembelajaran}

Media Pembelajaran banyak sekali jenis dan macamnya. Mulai yang paling kecil sederhana dan murah hingga media yang canggih dan mahal harganya. Ada media yang dapat dibuat oleh tenaga pengajar sendiri, ada media yang diproduksi pabrik. Ada media yang sudah tersedia di lingkungan yang langsung dapat kita manfaatkan, ada pula media yang secara khusus sengaja dirancang untuk keperluan pembelajaran.

Meskipun media banyak ragamnya, namun kenyataannya tidak banyak jenis media yang biasa digunakan oleh tenaga pengajar di sekolah. Beberapa media yang paling akrab dan hampir semua sekolah memanfaatkan adalah media cetak (buku). selain itu banyak juga sekolah yang telah memanfaatkan jenis media lain gambar, model, dan Overhead Projector (OHP) dan obyekobyek nyata. Sedangkan media lain seperti kaset audio, video, VCD, slide (film bingkai), program pembelajaran komputer masih jarang digunakan meskipun sebenarnya sudah tidak asing lagi bagi sebagian besar tenaga pengajar.

Banyaknya jenis media pembelajaran yang dapat digunakan pada prinsipnya bertujuan untuk mendukung aktivitas pembelajaran yang efektif, efisien, dan menarik. Untuk memudahkan dalam memilih dan menggunakannya, Anderson (1976) mengelompokkan media menjadi 10 golongan seperti yang terlihat pada Tabel 1 berikut ${ }^{4}$ :

\footnotetext{
${ }^{4}$ Arsyad, Media Pembelajaran, 2003, 22.
} 
Tabel 1. Kelompok Media dalam Pembelajaran

\begin{tabular}{|c|l|l|}
\hline No & \multicolumn{1}{|c|}{ Golongan Media } & Contoh dalam Pembelajaran \\
\hline I & Audio & $\begin{array}{l}\text { Kaset audio, siaran radio, CD, } \\
\text { telepon }\end{array}$ \\
\hline II & Cetak & $\begin{array}{l}\text { Buku pelajaran, modul, } \\
\text { brosur, leaflet, gambar }\end{array}$ \\
\hline III & Audio-cetak & $\begin{array}{l}\text { Kaset audio yang dilengkapi } \\
\text { bahan tertulis }\end{array}$ \\
\hline IV & Proyeksi visual diam & $\begin{array}{l}\text { Overhead transparansi } \\
\text { (OHT), Film bingkai (slide) }\end{array}$ \\
\hline V & $\begin{array}{l}\text { Proyeksi Audio visual } \\
\text { diam }\end{array}$ & Film bingkai (slide) bersuara \\
\hline VI & Visual gerak & Film bisu \\
\hline VII & Audio Visual Gerak & $\begin{array}{l}\text { Film gerak bersuara, } \\
\text { video/VCD, televisi }\end{array}$ \\
\hline VIII & Obyek fisik & $\begin{array}{l}\text { Benda nyata, model, } \\
\text { specimen }\end{array}$ \\
\hline IX & Manusia dan lingkungan & $\begin{array}{l}\text { Tenaga pengajar, } \\
\text { Pustakawan, Laboran }\end{array}$ \\
\hline X & Komputer /ICT & $\begin{array}{l}\text { CAI (Pembelajaran } \\
\text { berbantuan komputer), CBI } \\
\text { (Pembelajaran berbasis } \\
\text { komputer) }\end{array}$ \\
\hline
\end{tabular}

Berdasarkan perkembangan teknologi, media pembelajaran juga dapat dikelompokkan menjadi 4(empat) kelompok, yaitu (1) media hasil teknologi cetak, (2) media hasil teknologi audio-visual (3) media hasil teknologi yang berdasarkan komputer (berbasis ICT) dan (4) media hasil gabungan teknologi cetak dan komputer. ${ }^{5}$

Agar dapat memilih media pembelajaran yang tepat, penting untuk mempertimbangkan beberapa hal sebagai berikut: 6

1. Media yang digunakan sesuai dengan kurikulum

2. Isi informasi dan pengetahuan yang terkandung di dalamnya akurat dan baru

3. Isi informasi yang terdapat di dalamnya disampaikan dengan jelas

${ }^{5}$ Arsyad, Media Pembelajaran, 2007, 29.

\footnotetext{
${ }^{6}$ Sharon E Smaldino et al., Instructional Technology and Media for Learning (New Jersey: Pearson
} Merril Prentice Hall Inc, 2005). 
4. Media yang akan digunakan mampu memotivasi dan memancing minat belajar siswa

5. Media pembelajaran yang dipilih mampu melibatkan mental siswa dalam aktivitas pembelajaran

6. Kualitas teknis media pembelajaran yang akan digunakan baik

7. Media yang akan digunakan telah diuji coba sebelumnya

8. Media yang akan digunakan bebas dari kepentingan iklan komersial

9. Penggunaan media dilengkapi dnegan petunjuk tentang cara penggunaannya.

Teknologi cetak adalah cara untuk menghasilkan atau menyampaikan materi, seperti buku dan materi visual statis terutama melalui proses pencetakan mekanis atau fotografis. Kelompok media hasil teknologi cetak meliputi teks, grafik, foto atau representasi fotografik dan reproduksi. Materi cetak dan visual merupakan dasar pengembangan dan penggunaan kebanyakan materi pembelajaran lainnya. Teknologi ini menghasilkan materi pembelajaran dalam bentuk salinan tercetak.

Teknologi audio-visual adalah cara menghasilkan atau menyampaikan materi dengan menggunakan mesin-mesin mekanis dan elektronik untuk menyajikan pesan-pesan audio dan visual. Pengajaran melalui audi-visual jelas bercirikan pemakaian perangkat keras selama proses belajar, seperti mesin proyektor film, tape recorder, dan proyektor visual yang lebar. Jadi pengajaran melalui audio-visual adalah produksi dan penggunaan materi yang penyerapannya melalui pandangan dan pendengaran serta tidak seluruhnya tergantung kepada pemahaman kata atau simbol-simbol yang serupa.

Teknologi berbasis komputer merupakan cara menghasilkan atau menyampaikan materi dengan menggunakan sumber-sumber yang berbasis mikro-prosessor. Perbedaan antara media yang dihasilkan oleh teknologi berbasis komputer dengan yang dihasilkan dari dua teknologi lainnya adalah terletak pada informasi/materi yang disimpan dalam bentuk digital bukan dalam bentuk cetakan atau visual. Pada dasarya teknologi berbasis komputer menggunakan layar kaca untuk menyajikan informasi kepada siswa.

Berbagai jenis aplikasi teknologi berbasis komputer dalam pembelajaran umumnya dikenal sebagai computer-assisted instruction (pembelajaran dengan bantuan komputer). Aplikasi tersebut apabila dilihat dari cara penyajian dan tujuan yang ingin dicapai meliputi tutorial (penyajian materi pelajaran secara bertahap), drills and practice (latihan mengaplikasikan pengetahuan dan ketrampilan yang baru dipelajarai) dan database (sumber data yang dapat membantu siswa menambah informasi dan pengetahuannya sesuai dengan keinginan masing-masing). 
Teknologi gabungan adalah cara untuk menghasilkan dan menyampaikan materi yang menggabungkan pemakaian berupa bentuk media yang dikendalikan oleh komputer. Perpaduan beberapa jenis teknologi ini dianggap teknik yang paling canggih apabila dikendalikan oleh komputer yag memiliki kemampuan yang hebat seperti jumlah random access memory yang besar, hard disk yang besar kapasitasnya, dan monitor yang beresolusi tinggi ditambah denga periperal (alat-alat tambahan seperti videodisc player, perangkat keras lainnya yang digunakan bersama dalam satu jaringan) dan sistem audio.

\section{Jenis-Jenis Media Pembelajaran Berbasis ICT}

ICT atau TIK mencakup semua teknologi yang dapat digunakan untuk menyimpan, mengolah, menampilkan, dan menyampaikan informasi dalam proses komunikasi. Adapun yang termasuk teknologi ini adalah:

\section{Teknologi Komputer}

Media pembelajaran berbasis komputer atau bisa disebut pembelajaran berbantuan kompurter (computer assisted instructional/ CAI) adalah salah satu media pembelajaran yang sangat menarik dan mampu meningkatkan motivasi belajar peserta didik. Penggunaan komputer sebagai media pembelajaran interaktif dapat diwujudkan dalam berbagai bentuk, diantaranya program computer-assisted learning (CAL), konferensi komputer, surat elektronik atau elektronik mail (email), dan komputer multimedia yang kemudian disebut multimedia pembelajaran interaktif.

Pembelajaran melalui CAI ini, bersifat offline, sehingga dalam penggunaannya tidak tergantung pada adanya akses ke internet. Program pembelajaran berbantuan komputer ini memanfaatkan seluruh kemampuan komputer, terdiri dari gabungan hampir seluruh media, yaitu: teks, grafis, gambar, photo, audio, video, dan animasi. Seluruh media tersebut secara konvergen akan saling mendukung dan melebur menjadi satu media yang luar biasa kemampuannya. Salah satu keunggulan media komputer ini yang tidak dimiliki oleh berbagai media lain, ialah kemampuannya untuk menfasilitasi interaktifitas peserta didik dengan sumber belajar (content) yang ada pada komputer (man and machine interactivity) ${ }^{7}$.

${ }^{7}$ Bambang Warsita, Teknologi Pembelajaran (Jakarta: PT Rineka Cipta, 2008), 13738. 
2. Teknologi Multimedia

Media pembelajaran yang termasuk ke dalam teknologi multimedia adalah kamera digital, kamera video, player suara, player video, dll. Multimedia sering diartikan sebagai gabungan dari banyak media atau setidak-tidaknya terdiri lebih dari satu media. Multimedia dapat diartikan sebagai komouter yang dilengkapi dengan CD player, sound card, speaker dengan kemampuan memproses gambar gerak, audio, dan grafis dalam resolusi yang tinggi.

Program multimedia secara umum dapat digolongkan dalam empat kategori, yaitu:

1) Hiburan (entertaiment), yaitu seperti game dan film interaktif

2) Pendidikan, yakni untuk keperluan pendidikan formal, nonformal, pengayaan, dan penyegaran.

3) Refrensi, seperti ensiklopedia.

4) Bisnis, antara lain company profile, program financial dan lain-lain.

5) Teknologi Telekomunikasi

Yang termasuk media telekomunikasi adalah telepon seluler, dan faximile. Teknologi komunikasi ini sekarang berkembang semakin pesat. Kini tidak hanya dalam bentuk telepon seluler dan faximile saja namun bermacam-macam, seperti Handphone, e-mail, facebook, twitter dan lain sebagainya.

Namun seiring perkembangan yang semakin pesat, teknologi komunikasi dituntuk agar mampu memberikan manfaat yang banyak terhadap dunia pendidikan.

3. Teknologi Jaringan Komputer

Teknologi ini terdiri dari perangkat keras seperti LAN, internet, wifi, dan lain-lain. Selain itu juga terdiri dari perangkat lunak pendukungnya atau aplikasi jaringan seperti WEB, e-mail, html, java, php, aplikasi basis data dan lain-lain.

Salah satu bentuk pemanfaatan teknologi informasi untuk pembelajaran adalah pengembanagan e-dukasi.net yang berbasis internet. Edukasi.net adalah portal pendidikan yang menyediakan bahan belajar, fasilitas komunikasi, dan interaksi antar komunitas pendidikan. Situs atau portal pembelajaran yang dikembangkan ini dilengkapi dengan fasilitasfasilitas penyediaan bahan belajar yang meliputi seluruh mata pelajaran untuk seluruh jenjang dan jalur pendidikan, bimbingan belajar, bimbingan dan penyuluhan atau konsultasi, tutorial, remidial, email, forum diskusi, mailing list, dll. 
Dengan adanya teknologi internet ini sistem penyampaian dan komunikasi atau (delivery system and comunication) antara peserta didik dan tenaga pengajar, tenaga pengajar dengan tenaga pengajar atau peserta didik dengan peserta didik lain, dan peserrta didik dengan sumber belajar dapat dilakukan dengan berbagai bentuk dan cara, baik secara bersamaan (syncronous) maupun tidak (asyncronuos). ${ }^{8}$

Berdasarkan perkembangannya, awalnya media yang berbasis ICT hanya digunakan sebagai alat bantu mengajar tenaga (teaching aids) ${ }^{9}$. Namun dewasa ini perkembangan penggunaan ICT dalam pendidikan semakin pesat.

\section{Media Pembelajaran Berbasis ICT yang Diterapkan pada Sekolah Menengah di Kota Palopo}

Dari hasil penelitian kami terhadap data 5 sekolah menengah yang ada di kota Palopo yaitu MAN Palopo, SMA Negeri 1, SMA Negeri 6, SMP Negeri 3 dan SMP Negeri 8, dapat kami jelaskan bahwa nilai hasil Ujian Nasional sekolah menengah baik untuk tingkat pertama maupun tingkat atas terlihat setiap tahunnya cenderung mengalami peningkatan. Poin penting yang kami peroleh bahwa beberapa mata pelajaran yang oleh tenaga pengajarnya tidak menggunakan media pembelajaran berbasis ICT pun mengalami peningkatan hasil UN siswanya.

Sebelum membahas tentang hasil penelitian dari data yang ada dari pengamatan langsung di lokasi penelitian, perlu kami paparkan bahwa pemahaman para tenaga pengajar tentang media pembelajaran berbasis ICT atau TIK ternyata sangat beragam seperti yang dikemukakan oleh salah seorang pengajar pada SMP Negeri 8 Palopo yang memberikan komentar bahwa sepanjang pengajar melakukan pembelajaran melalui media komputer maka dapat dikatakan sebagai media pembelajaran berbasis ICT.

\footnotetext{
${ }^{8}$ Ibid., 159.

${ }^{9}$ Arif S Sadiman, Media Pendidikan (Jakarta: CV Rajawali, 1986), 7.
} 
Kenyataan yang diperoleh di lapangan ternyata banyak para pengajar menggunakan komputer/laptop hanya sebagai alat untuk melihat referensi yang ada pada file mereka, komputer yang dimaksud tidak dijadikan sebagai media pembelajaran yang aplikatif sehingga tidak terjadi interaksi langsung melalui media tersebut antara pengajar dan siswanya. Sehingga kami tidak memaknai pengajar yang hanya menggunakan media laptop hanya sekedar untuk melihat bahan/materi ajar tanpa menggunakan alat elektronik lain seperti LCD. Hal ini didasari pemahaman bahwa media pembelajaran yang berbasis ICT adalah media pembelajaran interaktif yang aplikatif.

Penguasaan TIK dalam profesionalitas kerja seorang tenaga pengajar sangat menunjang efektifitas dan keberhasilan dalam melaksanakan tugas. Namun, kecenderungan tenaga pengajar yang telah lama memberikan materi melalui buku referensi saja menjadikan mereka susah untuk melakukan inovasi terhadap media pembelajaran yang digunakan. Hal lain yang membuat para tenaga pengajar susah untuk beralih ke media pembelajaran berbasis ICT adalah karena faktor ketrampilan yang mereka miliki, dimana masih banyak para tenaga pengajar tersebut yang kurang memahami bagaimana mengoperasikan komputer/laptop.

Dari data yang kami peroleh terlihat di beberapa sekolah khususnya SMA Negeri 1 Palopo kecenderungan tenaga pengajarnya menggunakan media pembelajaran berbasis ICT dikarenakan setiap kelas yang ada pada sekolah tersebut difasilitasi oleh adanya LCD proyektor. Sehingga para pengajar sebagian besar menggunakan aplikasi media berbasis ICT sebagai sarana pembelajaran. Seperti yang dipaparkan pada bab sebelumnya bahwa media berbasis ICT ada 2 jenis yaitu media pembelajaran yaitu media pembelajaran yang siap pakai dan media pembelajaran yang harus melalui tahap perancangan atau desain terlebih dahulu sebelum digunakan. Kenyataan di lapangan kami temukan bahwa sebagian besar para pengajar menggunkan media pembelajaran yang siap pakai apakah itu media 'konvensional' seperti buku referensi ataupun media berbasis ICT.

Adapun jenis/golongan media pembelajaran berbasis ICT yang digunakan oleh pengajar di 5 (lima) lokasi menengah tersebut yaitu :

1. Proyeksi Visual Diam, menggunakan komputer dan LCD proyektor sebagai media pembebelajarnnya namun materi yang disampaikan hanya berupa wacana/tulisan saja tanpa memberikan sentuhan unsur yang berkaitan dengan multimedia, sehingga siswa merasa apa yang disampaikan oleh pengajara tersebut tidak jauh beda dengan buku referensi. 
2. Proyeksi Audio Visual Diam, pada media pembelajaran golongan ini, sudah memberikan unsur multimedia karena sudah menggunakan sentuhan visual di dalamnya, contoh seperti pemaparan materi pembelajaran beberapa pengajar dengan menggunakan slide/power poin.

Proyeksi Audio Visual Gerak, untuk golongan ini hanya ada beberapa orang pengajar saja yang menggunakan metode ini dimana dalam pemaparan materi ajarnya menyisipkan unsur visual gerak/film atau video yang berkenaan dengan materi yang disampaikan.

\section{Kemampuan Tenaga Pengajar dalam Menerapkan Media Pembelajaran Berbasis ICT}

Kemampuan para pengajar dalam menerapkan media pembelajaran berbasis ICT, tidak terlepas dari skill atau ketrampilan mereka dalam menggunakan aplikasi pada komputer. Tidak dipungkiri masih banyak pengajar di sekolah-sekolah pun bahkan di tingkat Perguruan Tinggi yang belum mahir atau tidak mau menggunakan komputer sebagai media pembelajarannya. Hal ini bisa jadi karena mereka sudah merasa "nyaman" dengan media yang digunakan selama ini atau mereka merasa "sudah tua" untuk mempelajari alat yang bernama komputer tersebut.

Disamping itu pula, menurut data yang diperoleh menyebutkan bahwa mampu tidaknya pengajar membawakan materi ajarnya dengan aplikasi komputer dipengaruhi pula oleh basis ilmu yang dimiliki oleh pengajar tersebut, karena masih ada beberapa pengajar yang konsentrasi bidang ilmu yang dibawakan tidak sesuai dengan mata pelajaran yang diajarkan. Hal tersebut terjadi pada MAN Palopo dimana pengajar Mata Pelajaran Geografi adalah seorang Sarjana Agama. Namun berkat keinginan dan minat yang besar oleh pengajar yang bersangkutan ditambah dengan dukungan pimpinan sekolah untuk mendukung pengajar tersebut mengikuti pelatihan keselarasan/kesesuain bidang ilmu dengan materi yang diajarkan sehingga pengajar tersebut saat ini sudah mampu membawakan materi bidang pengajarannya dengan baik.

Kemampuan pengajar dalam melakukan inovasi untuk media pembelajaran yang digunakan tergantung sarana dan prasarana yang disediakan oleh pihak sekolah seperti yang terlihat pada kondisi pada SMA Negeri 1 Palopo dimana setiap kelasnya telah disediakan fasilitas LCD Proyektor sehingga membuat pengajar yang ada pada sekolah tersebut terdorong untuk menggunakan alat tersebut dalam pembelajarannya sehingga menjadikan tujuan pembelajaran dapat tercapai secara maksimal. 
Meski demikian, menurut pantauan kami di beberapa sekolah yang kami teliti disediakan fasilitas LCD proyektor oleh pihak sekolah namun masih banyak pengajar yang tidak mau menggunakan alat tersebut sebagai media perantara penyampaian materi ajar dengan berbagai alasan.

\section{Pengaruh Media Pembelajaran Berbasis ICT terhadap Hasil Ujian Nasional Siswa}

Kelulusan siswa menengah saat ini tidak lagi terfokus hanya dengan melihat hasil/nilai Ujian Nasional (UN) saja. Hal ini dikemukakan oleh Menteri Pendidikan Dasar \& Menengah, Anies Baswedan. Hal ini disampaikan ke pihak sekolah mengingat pertimbangan bahwa siswa sekolah menengah menjalani proses pendidikan selama 3 tahun sehingga penilaian akhir untuk menilai kelulusan siswa tersebut hendaknya ditentukan dari hasil belajar yang mereka capai selama 3 tahun tersebut, sehingga hal tersebut tidak lagi merugikan pihak siswa yang merasa tidak mendapatkan keadilan dengan kelulusan yang ditentukan oleh Ujian Nasional semata.

Data yang kami peroleh untuk kelima sekolah menengah yang ada di Kota Palopo dalam kurun waktu 3 tahun terakhir menjelaskan bahwa semua siswa pada sekolah tersebut dalam 3 (tiga) tahun terakhir ini lulus $100 \%$.

Dari gambaran data yang ada dengan melihat nilai rata-rata dari hasil Ujian Nasional Siswa dalam 3 (tiga) tahun terakhir dan jenis media pembelajaran yang digunakan oleh para pengajarnya, terlihat bahwa cenderung terjadi perbedaan hasil ujian yang lebih baik bagi siswa yang pengajarnya menggunakan media pembelajaran berbasis ICT dibandingkan dengan pengajar yang tidak menggunakan ICT dalam media pembelajarannya. Jika membandingkan dalam lingkup sekolah yang sama antara pengajar yang menggunakan media pembelajaran berbasis ICT dengan yang tidak menggunakan media pembelajaran berbasis ICT tampak terjadi peningkatan nilai siswa disetiap tahunnya pada bidang studi yang media pembelajarannya berbasis ICT.

Demikian pula jika membandingkan satu sekolah dengan sekolah yang lain untuk bidang studi yang sama terlihat adanya peningkatan nilai yang lebih baik terhadap siswa yang pengajarnya menggunakan media pembelajaran berbasis ICT dibandingkan dengan yang tidak menggunakan ICT sebagai media pembelajarannya. 
Berkenaan dengan hal tersebut, kami juga mendapatkan informasi dari beberapa alumni sekolah tersebut melalui dialog-dialog ringan, sebagian besar dari mereka sangat sependapat bahwa pembelajaran yang menggunakan media ICT lebih baik, karena mereka bisa lebih fokus dan menikmati pembelajaran tersebut apalagi jika disajikan dalam bentuk presentasi yang menarik membuat mereka lebih paham dan cenderung dapat lebih mengingat pemaparan oleh pengajar tentang materi pelajaran tersebut dibandingkan dengan menyimak pemaparan pengajar-pengajar yang masih menggunakan media konvensional, seperti buku-buku referensi yang terkesan monoton.

\section{Penutup}

Media pembelajaran berbasis ICT sangat berpengaruh terhadap hasil belajar siswa khususnya nilai dari Ujian Nasional pada 3 (tiga) tahun terakhir) ini. Dari gambaran data yang kami peroleh terlihat nilai rata-rata dari hasil Ujian Nasional Siswa dalam 3 (tiga) tahun terakhir di 5 (lima) sekolah menengah yang berada di kota Palopo dan jenis media pembelajaran yang digunakan oleh para pengajarnya, terlihat bahwa cenderung terjadi perbedaan hasil ujian yang lebih baik bagi siswa yang pengajarnya menggunakan media pembelajaran berbasis ICT dibandingkan dengan pengajar yang tidak menggunakan ICT dalam media pembelajarannya.

Tenaga pengajar pada 5 (lima) sekolah menengah di kota Palopo masih sebagian kecil yang paham dan aktif menggunakan media pembelajaran berbasis ICT secara aplikatif, hal ini dikarenakan masih kurangnya ketrampilan dalam memahami ilmu komputer yang dimiliki oleh tenaga pengajar tersebut. Sebagian besar menggunakan komputer hanya sebagai sarana penyimpanan materi dalam bentuk teks, materi tidak diaplikasikan dalam bentuk pengajaran seperti multimedia.

Kurang optimalnya sarana dan prasarana yang disediakan oleh beberapa sekolah untuk mendukung penerapan media pembelajaran berbasis ICT, sehingga membuat para tenaga pengajarnya tidak tertantang untuk berinovasi dalam menerapkan media pembelajaran berbasis ICT guna mendapatkan hasil pembelajaran yang lebih baik. 
Penggunaan Media Pembelajaran Berbasis ICT ...

\section{Daftar Pustaka}

Arsyad, Azhar. Media Pembelajaran. Jakarta: Departemen Pendidikan Nasional Jenderal Pendidikan Dasar Menengah Direktorat Tenaga Kependidikan, 2003.

_- - Media Pembelajaran. Jakarta: Raja Grafindo Persada, 2007. Sadiman, Arif S. Media Pendidikan. Jakarta: CV Rajawali, 1986.

Smaldino, Sharon E, Deborah L Lowther, Clif Mims, and James D Russell. Instructional Technology and Media for Learning. New Jersey: Pearson Merril Prentice Hall Inc, 2005.

Warsita, Bambang. Teknologi Pembelajaran. Jakarta: PT Rineka Cipta, 2008. 
